\title{
BIOGRAPHY VISUALIZATION OF SULTAN THAHA SAIFUDDIN BASED ON ARCGIS STORY MAPS IN JAMBI PROVINCE
}

\author{
Hendra Gunawan ${ }^{1}$, M. Azir ${ }^{2}$, Dodi Harianto ${ }^{3}$, Abdul Halim \\ 1, 2, 3, 4 UIN Sulthan Thaha Saifuddin Jambi \\ Jl. Jambi-Muara Bulian KM. 16 Simp. Sungai Duren Kab. Ma. Jambi
}

Email corresponding: hendragunawan@uinjambi.ac.id

\begin{tabular}{|c|c|c|}
\hline Submitted: & Accepted: & Published: \\
$27-06-2021$ & $29-06-2021$ & $30-09-2021$ \\
\hline
\end{tabular}

\begin{abstract}
The introduction of new technologies for historical studies presents an opportunity to make historical studies more accessible to the public. The ArcGIS platform has facilitated this effort and offers interesting ways to do this, including the Story Map program. Part of the cloud-based online ArcGIS platform, the story map application enables the integration of narratives, images, and maps in an easy-to-use format. This paper tries to apply this technology in the theme of Visualization of Biography of Sultan Thaha Saifuddin Based on ArcGIS Story Map in Jambi Province. Many similar writings discuss the biography of Sultan Thaha Saifuddin with a historical approach but do not look at it from a spatial perspective. The focus of historical research only focuses on events and periodization. Therefore, this article describes the biography of Sultan Thaha Saifuddin so that other historians can also apply this technology to their work.
\end{abstract}

Key words: Biography, ArcGIS Story Map, Sultan Thaha Saifuddin, Visualization

\section{Introduction}

Geographic Information Systems (GIS) is a technological development that provides new opportunities for immersive content while broadly engaging public audiences with complex multivariate data sets. One of the latest technological results in GIS is Story Map which can provide support for engaging and direct scientific storytelling, using multimedia content and narrative texts for effective visualization of spatial data (Antoniou et al., 2021). Thus, Story maps can be used to disseminate and understand scientific findings to a wider non-technical audience.

The advantage of GIS is that it presents data spatially and is able to deepen the analysis of phenomena (Imam, 2019). This is an opportunity for collaboration with crossdisciplinary sciences, namely history. According to Lombard (2005), none of the historical designs will achieve the goal without considering geographical factors (Rusdi Effendi, 2020). One of the historical themes that are interesting to study using a Story Map is the Biography of Sultan Thaha Saifuddin.

The history of Sultan Thaha Saifuddin's struggle against Dutch colonialism cannot be separated from spatial studies. Starting from the appointment of Sultan Thaha Saifuddin as the highest leader in Jambi, and his flight to several areas, until his death, of course, requires visualization using the ArcGIS Story Map. Therefore, in this article, we will explain the journey of Sultan Thaha Saifuddin from Jambi to Merangin, Bangko, Bungo, Tebo, and the upstream areas.

\section{Methods}

To visualize the biography of Sultan Thaha Saifuddin using a Story Map, which focuses on presenting the natural and anthropogenic environment of the area in combination with its historical value, various types of data sets have been compiled, either from recent photo taking or through several related websites.

A visualization of the biography of Sultan Thaha Saifuddin has been created using the ArcGIS Platform, although other software (free or commercial) is also available. After sifting through outdated software, the selection is based on the fact that all available data can be processed within the chosen platform. In addition, all the necessary tools and applications are on this platform without the need to use different software to achieve the same result and without the need for programming.

Thus, all available vector and grid spatial data, along with descriptive ones, were first collected, homogenized, and organized into a geodatabase via ArcGIS 
software. In addition, the geodatabase also contains the necessary feature layers to be used during fieldwork. ArcGIS Collector, an application available on the web and mobile versions (for Android and iOS devices, tablets, or smartphones) via the ArcGIS platform is used to ensure the accurate geographic location of sites of interest and to collect and update real-time, spatial, and descriptive data. Using a web map, created and shared via ArcGIS Pro, which contains a class of features devoted to data collection, points corresponding to sites of interest are collected using maps or GPS signals, while descriptive text and photos or videos complete the fields provided in the appropriate attribute table. layers as attachments. After sharing all the available layers of information to ArcGIS Online, 2D web maps, finally creating a story map.

\section{Results and Discussion}

Raden Thaha Adiningrat or better known as Sultan Thaha Saifuddin is the son of Sultan Muhammad Fachruddin (Ona Yulita, 2019). He was born in the Tanah Select Palace, Kampung Gedang, Jambi Sultanate, in 1816 (Elsbeth Locher-Scholten, 2008) . Jambi's strategic position made this area much ogled by big kingdoms, including Europeans, especially the Dutch.

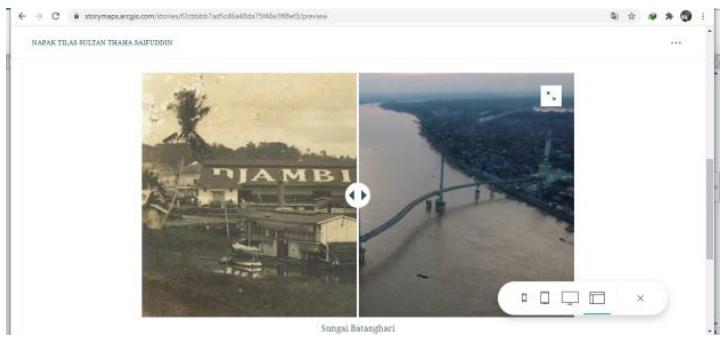

Picture 1: Batanghari River Comparison

Since Sultan Thaha was a teenager, he has shown his dislike for the Netherlands (Lindayanti, 2013). The triggering factor for the resistance of Sultan Thaha was the pressure of Dutch control through agreements that always burdened the Jambi Sultanate. The impact of the agreement is the establishment of the headquarters of the Dutch patrol in Muara Kumpeh, which is a strategic place as the exit and entry of cruise in the al Iran river Batang day (Masjkuri, 1979). A place that is often used for monitoring the central government of the Jambi Sultanate, both in the defense and economic fields (Ona Yulita, 2019).

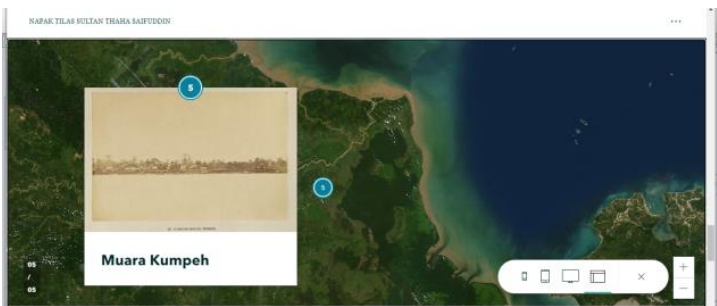

Picture 2: Muara Kumpeh

In 1855, Sultan Thaha ascended the throne to become the Sultan of Jambi replacing Sultan Abdurrahman. The response of Sultan Thaha who always opposed Dutch policies was considered a big threat by the Dutch colonial side (Masjkuri, 1979). Various kinds of negotiations carried out through the Palembang Residency did not produce any results. So in 1858, the Dutch sent their troops through the Kumpeh river to capture Sultan Thaha. Feeling pressed, Sultan Thaha left the Jambi Sultanate and hid in Muara Tembesi (Ona Yulita, 2019) .

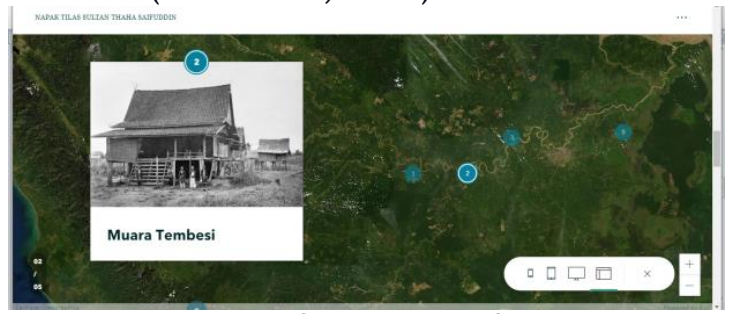

Picture 3: Muara Tembesi

In Muara Tembesi, Sultan Thaha was assisted by Tumenggung Mangku Negoro from Bangko. They formed a commando force to repel the Dutch troops who controlled several areas around the Jambi Sultanate. The battle command was divided by region and was led directly by Sultan Thaha and Tumenggung Mangku Negoro. From the Muara Tembesi area to Padang which includes Tebo, Bungo, Jujuhan and Tungkal under the command of Sultan Thaha and his brother Prince Diponegoro. The areas of Batang Tembesi, Secepat, Sungai Tenang, Merangin, Mesumai, Tantan, Pelepat, Senamat, Tabir to Kerinci were under the command of Tumenggung Mangku Negoro and his commander Prince Haji Umar bin Pangeran M. Yasir (Masjkuri, 1979) . The existence of a command division area to facilitate the coordination of the Dutch army's attack.

On the other hand, along with the departure of Sultan Thaha from the Jambi Sultanate, the Dutch appointed a "puppet" Sultan to seek profit (Elsbeth LocherScholten, 2008). Nevertheless, the position of Sultan Thaha is still recognized by some Jambi people as the highest leader of the 
Jambi Sultanate. Therefore, the Jambi region was separated into two jurisdictions. The downstream area is controlled by the Dutch "puppet" Sultan and the upstream area is controlled by Sultan Thaha (Masjkuri, 1979). Downstream areas include Kuala Tungkal, Sabak, Kumpeh, Muara Jambi, Jambi and Batanghari. The upstream area includes Muara Tembesi, Bangko, Tebo, Bungo, and the surrounding area.

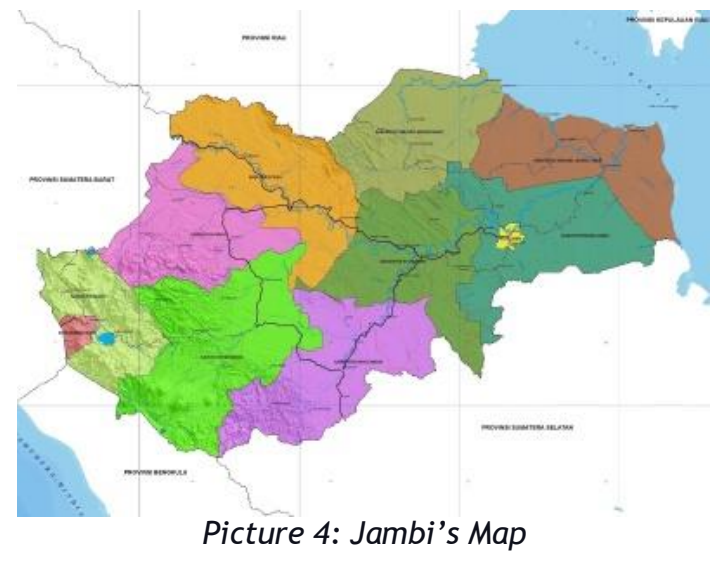

The Sultans appointed by the Dutch to replace Sultan Thaha were Abdurrahman Nazaruddin with the title Sultan Ratu Ahmad Nazaruddin in 1858; Prince Ratu Martadiningrat with the title Sultan Ratu Muhammad Mahiluddin (Muhyidin) in 1881; and Prince Ratu Cakranegara with the title Sultan Ahmad Zainuddin in 1886 (Ona Yulita, 2019) . Although part of the Jambi Sultanate was controlled by the Dutch, the Dutch desire to capture Sultan Thaha still continued. Not without reason, there were many battles between the Dutch and Sultan Thaha in several areas. This certainly endangered the existence of the Dutch in Jambi.

In order to pursue the existence of Sultan Thaha who was considered to be endangering the existence of the Dutch, in 1901 a massive attack was carried out on Muara Tembesi (Lindayanti, 2013). Many soldiers of Sultan Thaha died at that time, there are even some sources who say that Sultan Thaha also died during the war in Muara Tembesi (Ona Yulita, 2019). However, the record regarding the death of Sultan Thaha is still being debated. Other information says that Sultan Thaha managed to escape from the Dutch attack in Muara Tembesi and then hid in Betung. There are also sources who say that Sultan Thaha died on the Aro River in 1904 and was buried in Tebo. Another source said that Sultan Thaha had fled to Betungbedarah. Some even claim that Sultan Thaha fled to West Sumatra and died there (Masjkuri, 1979).

Based on differences of opinion regarding the death of Sultan Thaha, in 1978 through a seminar on Sultan Thaha Saifuddin held in Jambi, concluded that;

Since the year of Sultan Thaha's death has already been written in literary books with reliable sources even though the source is from the Netherlands, the opinion that Sultan Thaha died on April 26, 1904, in the battle at Betungbedarah, should be taken as a guide. While the tomb of Sultan Thaha is in Muara Tebo (Masjkuri, 1979) .

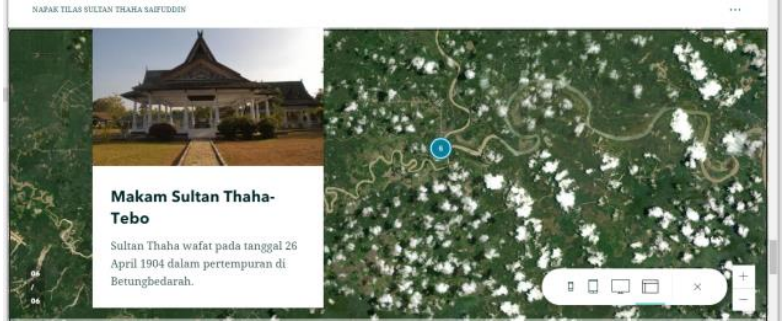

Picture 5: Tomb of Sultan Thaha in Tebo

\section{Conclusion}

Sultan Thaha Saifuddin preferred areas around the Batang Hari river, such as Muara Tembesi, Betungbedarah, Tebo, Bungo, Muara Kumpeh, and the area around the Batanghari River . Spatial analysis shows that the Batang Hari river was indeed a transportation route at that time, therefore the flight and wars that occurred between Sultan Thaha Saifuddin and the Dutch were more common around the Batang Hari River. Story maps are very useful in visualizing the history of the biography of Sultan Thaha Saifuddin, but it is also able to help answer historical problems spatially.

\section{References}

Antoniou, V., Nomikou, P., Papaspyropoulos, K., Karatzaferis, O., Vlasopoulos, O., Stentoumis, C., \& Kalisperakis, I. (2021). A Journey to Salamis Island (Greece) using a GIS Tailored Interactive Story Map Application. Gistam, 187-194. https://doi.org/10.5220/0010440701870 194

Elsbeth Locher-Scholten. (2008). Kesultanan Sumatra dan Negara Kolonial, hubungan Jambi-Batavia (1830- 1907) dan Bangkitnya Imperialisme Belanda. KITLV.

Imam. (2019). PERAN SISTEM INFORMASI Imam Arifa' illah Syaiful Huda. Nazharat, 24, 13-22. 
Lindayanti. (2013). Jambi Dalam Sejarah 1500-1942. Pusat Kajian Pengembangan Sejarah dan Budaya Jambi.

Masjkuri. (1979). Sultan Thaha Syaifuddin.

Ona Yulita, D. N. (2019). Jurnal Kajian Kegamaan dan Kemasyarakatan. Jurnal Fuaduna: Jurnal Kajian Keagamaan Dan Kemasyarakatan, 3(1), 1-12. https://doi.org/10.22373/jiif.v13i2.72.

Rusdi Effendi. (2020). BUKU AJAR GEOGRAFI DAN ILMU SEJARAH. Universitas Lambung Mangkurat. 